\title{
Does Microvascular Function Play a Role in the Etiology of Bell's Palsy?
}

\section{Bell's Palsi Gelişimi ve Prognozununda Mikrovasküler Fonksiyonun Rolü Var mıdır?

\author{
๑ Arzu Karaman Koç, ๑ Hasan Emre Koçak, • Bilgen Çakıl Erdoğan* , • Hüseyin Avni Ulusoy, \\ ๑ Mehmet Yiğitbay, ๑ Harun Acıpayam, • Kamil Hakan Kaya
}

Bakırköy Dr. Sadi Konuk Training and Research Hospital, Clinic of Otorhinolaryngology, Istanbul, Turkey

${ }^{*}$ Bakırköy Dr. Sadi Konuk Training and Research Hospital, Clinic of Dermatology, Istanbul, Turkey

\section{Abstract}

Aim: The aim of our study was to investigate whether systemic microvascular function affects the development and prognosis of Bell's palsy (BP) or not.

Methods: Sixty patients, who were admitted to our hospital between June 2017 and May 2018 and diagnosed with BP, were included as the BP group, and 60 healthy volunteers who came to the hospital for health screening, were included as the control group in our study. The BP group was examined 3 months after the treatment and were divided into two groups according to the House-Brackmann Grading system. Capillary density (CD) and post-occlusive reactive hyperemia (PORH) values were measured by performing videocapillaroscopic examination through the nail fold for microvascular function, and statistical analysis was carried out among the groups.

Results: The video-capillary results revealed that there was no significant difference in $C D$ and PORH values $(p>0.05)$. In the complete recovery and incomplete recovery group, the $C D$ and PORH values were not significantly different ( $p>0.05$ ).

Conclusion: To the best of our knowledge, our study is the first study conducted in the literature. Even though the role of specific mechanisms in BP has not been fully understood, there was no significant difference between the BP patients and the healthy subjects and between the recovery and incomplete recovery groups with the capillaroscopic examination. It has been thought that the CD and PORH values were normal in the BP patients and that a microvascular mechanism was not a possible factor for the development and prognosis.

Keywords: Bell's palsy, capillaroscopy, microvascular function, etiology
Amaç: Çalışmamızın amacı sistemik mikrovasküler fonksiyonun Bell's palsi (BP) gelişimini ve prognozunu etkileyip etkilemediğini araştırmaktır.

Yöntemler: Çalışmaya Haziran 2017 ve Mayıs 2018 tarihleri arasında hastanemize başvuran BP tanısı almış 60 hasta BP grubu olarak ve sağlık taraması için hastaneye gelen 60 sağlıklı gönüllü kontrol grubu olarak dahil edildi. BP grubu tedaviden 3 ay sonra muayene edilerek House-Brackmann derecelendirme sistemine göre iki gruba ayrıldı. Mikrovasküler fonksiyon için tırnak yatağından video-kapilleroskopik inceleme yapılarak kapiller dansite $(C D)$ ve post-okluzif reaktif hiperemi (PORH) değerleri ölçüldü ve gruplar arasında istatistiksel analiz yapıldı.

Bulgular: Video-kapilleroskopik sonuçlarda CD ve PORH değeri anlamlı ( $p>0,05)$ farklılık göstermemiştir. Tam iyileşme ve tam iyileşme olmayan gruplarında ortalama $C D$ ve $P O R H$ değeri anlamlı $(p>0,05)$ farklılık göstermemiştir.

Sonuç: Çalışmamız bildiğimiz kadarıyla literatürde yapılan ilk çalışmadır. BP'de spesifik mekanizmaların rolü tam anlaşılmamasına rağmen kapilleroskopik inceleme ile BP hastaları ile sağlıklı kişiler arasında ve iyileşen, iyileşmeyen gruplar arasında anlamlı farklılık saptanmamıştır. BP hastalarında CD ve PORH değerlerinin normal olduğunu ve mikrovasküler bir mekanizmanın gelişim ve prognoz üzerine muhtemel bir faktör olmadığı düşünülmüştür.

Anahtar Sözcükler: Bell palsi, kapilleroskopi, mikrovasküler fonksiyon, etiyoloji
Address for Correspondence/Yazışma Adresi: Hasan Emre Koçak, Bakırköy Dr. Sadi Konuk Training and Research Hospital, Clinic of Otorhinolaryngology, İstanbul, Turkey E-mail: drhekbb@gmail.com ORCID: orcid.org/0000-0002-9859-0146 Received/Geliş Tarihi: 22 November 2019 Accepted/Kabul Tarihi: 07 December 2019
${ }^{\circ}$ Copyright 2020 by The Medical Bulletin of istanbul Haseki Training and Research Hospital The Medical Bulletin of Haseki published by Galenos Yayinevi.

Telif Hakkı 2020 istanbul Haseki Eğitim ve Araştırma Hastanesi Haseki Tıp Bülteni, Galenos Yayınevi tarafından yayınlanmıştır. 


\section{Introduction}

Bell's paralysis (BP-idiopathic peripheral facial paralysis) is an acute, idiopathic peripheral nerve impairment involving the facial nerve, showing muscle weakness on the same side of the face. It has got its name from Sir Charles Bell who first described the anatomy of the facial nerve in 1821 (1). Although the annual incidence of BP is 20-30 per 100,000 persons, it is higher in patients over 65 years old (59 out of 100,000). Men and women are equally affected by the disease but it is a little bit more common among pregnant women (2).

Despite the abundance of research on the pathophysiology of $\mathrm{BP}$, the exact etiology is still uncertain. From these, the reactivation of latent herpes simplex virus type I and herpes zoster virus is the most commonly accepted cause (3). However, viral infection, ischemic neuropathy, genetic predisposition, autoimmune reactions, and microvascular failure of the vasa nervorum are still the main hypotheses for the causes of BP (4). None of these factors has been proven to be the exact etiologic factor $(3,4)$. There are studies demonstrating the association between BP and vascular injury-related disorders. BP is susceptible to ischemic injury due to lower microvascular vascularization and anastomosis of the labyrinthine segment in the intratemporal part of the facial nerve (5). Moreover, the location of the mental foramen that is the segmental entry of the labyrinthine, along with the facial nerve in the narrowest part of the bone canal and low vascularity have a negative effect on the resolution of inflammation and nerve edema caused by BP. Microvascular injury is an important etiology in the textbooks since this segment does not have collateral vessels (6). However, despite the anatomical evidence, the vascular etiology of BP has still not been clarified explicitly.

Evaluation of systemic microvascular density and reactivity is essential for cardiovascular disease pathophysiology and cardiovascular risk classification (7). Furthermore, cutaneous microcirculation is an accessible and acceptable vascular bed for evaluating systemic microcirculation reactivity (8). Moreover, it has been shown that the cutaneous microvascular reactivity was associated with the function of vascular beds in different regions (9). Capillary density (CD) and reactivity, which is a predictive indicator for vascular diseases, can be measured non-invasively using the videocapillaroscopy method (10).

Although the role of microvascular dysfunction in BP has not yet been proven, this measurement can give us information about the vascular risk and pathophysiology in BP. Therefore, we aimed to investigate the clinical significance of microvascular function that can be determined by nail fold capillaroscopy in the development and prognosis of BP.

\section{Methods}

\section{Ethics Committee}

Our study was conducted as a prospective casecontrol study after receiving the approval from the Local Ethics Committee of Bakırköy Dr. Sadi Konuk Training and Research Hospital (ethics committee no: 2017-08).

\section{Participants}

Sixty patients, who were admitted to our hospital between June 2017 and May 2018 and diagnosed with BP, were included as the BP group, and 60 healthy volunteers who came to the hospital for health screening, were included as the control group in our study. The BP diagnosis was made in patients with acute-onset, idiopathic, unilateral facial weakness of the seventh cranial nerve. Physical examination, systolic and diastolic blood pressure measurement, microscopic otologic examination, and hematological and biochemical analysis were performed in all patients. Nail fold videocapillaroscopic examinations were performed by a dermatologist. The dermatology physician did not know in which group the patients were included.

\section{Inclusion Criteria}

In the BP group, patients, who did not previously receive steroid treatment and were admitted within 7 days from the onset of their complaints and evaluated as idiopathic BP, were included in the study. Patients with no known chronic disease, no evidence of active infection within the last 1 month, no medication use within the last 1 month and no otologic or cardiovascular disease and no surgery history and, who came to the outpatient clinic for health screening, were included in the control group.

\section{Exclusion Criteria}

Smokers, patients with comorbid diseases such as chronic cardiovascular, microvascular disease, chronic primary hypertension, Diabetes Mellitus type 1, 2, chronic obstructive pulmonary disease, asthma, hyperlipidemia, hypercholesterolemia, obesity, and metabolic syndrome, patients who have an intracranial mass proven by magnetic resonance imaging, pregnant women and patients with infective, metabolic, central and peripheral nervous system diseases were not included in the study.

\section{Nail Fold Capillaroscopic Evaluation}

The microcirculation test was carried out after 20 min rest in the supine position in a quiet environment and at a stable temperature $\left(23^{\circ} \mathrm{C} \pm 1\right)$. The imaging was performed on the nail fold at the dorsum of the fourth finger of the non-dominant hand while the patient was in a sitting position. The patient's arm was kept at the heart level and a vacuum pad was placed under the arm to prevent mobilization. 
The capillaroscopic examination was performed by a dermatologist using a videocapillaryoscopy system with a magnification of 500x (Dino-lite digital microscope AM4113-N5UT, Dino-Lite Europe, Netherlands). The CD was calculated by counting the number of capillaries in a $1 \mathrm{~mm}^{2}$ area three times and by taking their arithmetic means. To calculate post-occlusive reactive hyperemia (PORH), a cuff of blood pressure device was applied on the patient's arm from which the measurement was taken, and the blood flow was interrupted for 3 minutes by providing a $50 \mathrm{mmHg}$ higher pressure than the systolic pressure. The PORH measurement was calculated by remeasuring the number of capillaries after 60 seconds (11).

\section{Evaluation of Facial Paralysis}

The House-Brackmann (HB) Facial Nerve Grading system was used in the evaluation of facial paralysis (12). The BP group was examined 3 months after the treatment and was divided into two groups according to HB score: those with grade 2 and above as the incomplete recovery group and those with grade 1-2 as the complete recovery group.

\section{Treatment Protocol}

All patients received systemic (oral) methylprednisolone (Prednol-L16mg tb ${ }^{\circledR}$ and $4 \mathrm{mg}$ tb $^{\circledR}$, Mustafa Nevzat, Istanbul, Turkey) at the full dose of $1 \mathrm{mg} / \mathrm{kg}$ for 3 days, the next days at $8 \mathrm{mg}$ declining doses for 14 days, and 500 mg systemic (oral) valacyclovir (Valtrex-500mg tb ${ }^{\circledR}$, Glaxo Smith Kline, UK) three times daily for 7 days.

\section{Statistical Analysis}

Mean, standard deviation, lowest and highest median, frequency and ratio values were used in the descriptive statistics of the data. The Kolmogorov-Smirnov test was used to measure the distribution of the variables. The Mann-Whitney $U$ test was used in the analysis of the quantitative data. The Wilcoxon test was used in the analysis of repeated measurements. The chi-square test was used in the analysis of the qualitative data. SPSS Statistics V22.0 software was used in the analyses.

\section{Results}

The mean age was $31.7 \pm 8.4$ years in the BP group and $32.5 \pm 8.0$ years in the control group. There were 24 females, 36 males in the BP group and 30 males and 30 females in the control group. The patients' age and gender distribution in the BP and control groups were not significantly different $(p>0.05)$. The BP group was examined 3 months after the treatment; according to the HB grading system, there were 13 patients with grade 2 and above in the incomplete recovery group and 47 patients with grade 1-2 in the complete recovery group.
Based on the videocapillaroscopic results, the mean CD value was $95.5 \pm 7.5$ in the BP group and $96.4 \pm 7.2$ in the control group. The mean PORH value was $95.8 \pm 7.5$ in the BP group and $96.8 \pm 6.7$ in the control group. The CD and $\mathrm{PORH}$ values were not significantly different between the groups ( $p>0.05$ ) (Table 1).

The mean $C D$ value in the complete recovery and incomplete recovery groups was $95.8 \pm 8$ and 94.6 \pm 5.6 , respectively. The mean $\mathrm{PORH}$ value in the complete recovery and incomplete recovery groups was $96.7 \pm 7.8$ and $92.7 \pm 5.3$, respectively. The mean $C D$ and $P O R H$ values were not significantly different between the groups ( $p>0.05)$ (Table 2).

\section{Discussion}

In the case-control study we presented, there is new evidence regarding the role of systemic microvascular function in the prognosis of BP and as far as we know, this is the first study in the literature. The basic findings of the study can be summarized as follows; the capillary density and reactivity showing the microvascular function were observed to be at the same level in the normal population and BP patients. Moreover, the microvascular function was observed to be at the same level between the complete and incomplete recovery groups after the treatment. In line with this data, microvascular dysfunction does not provide evidence as a possible factor in the development and prognosis of $\mathrm{BP}$.

Microcirculation blood flow has an important role in terms of oxygen and nutrition supply to the healthy tissues and organs (13). Capillaroscopy is the best method to monitor microcirculatory changes in healthy subjects and patients (10). Capillary rarefaction (a reduction in the density of capillaries) seems to correlate with end-organ damage as well as supports the correlation between hypertensive myocardial disease and low myocardial capillary density (14). In addition to that, the correlation has been demonstrated between the left ventricular hypertrophy and skin microcirculation independent of blood pressure levels (15). In fact, a reduction in the capillary density at the capillary bed level provokes tissue perfusion damage and causes end-organ damage. It leads to complications in organs such as the eye (retinopathy), brain (lacunar stroke), kidney (microalbuminuria), and heart (heart failure) $(16,17)$. Moreover, the finding of microcirculation dysfunction in patients without cardiovascular disease has been attributed to a poor prognosis (18). In our study, we also found the capillary density and reactivity that show the systemic microvascular function in BP, a vascular hypothesis in the etiology, to be statistically insignificant both in the normal population and in the complete and incomplete recovery groups. 
Although the virus has never been isolated from the serum of patients with Bell's palsy, the viral hypothesis has been commonly accepted. $(19,20)$ Thus, the evidence for a viral hypothesis is indirect and is based on clinical observations and changes in viral antibody titers (21). Moreover, although the underlying cause may be viral, the cause of the paralysis itself is controversial; it may be viral neuropathy secondary to viral infection alone or ischemic neuropathy (22). The intratemporal part of the facial nerve is preserved within a bony canal, called the fallopian canal. This section is divided into five segments: meatal segment, labyrinthine segment, geniculate ganglion, tympanic segment and mastoid segment. The lengths of these segments are 13-15 $\mathrm{mm}, 3-4 \mathrm{~mm}, 8-11 \mathrm{~mm}$ and $10-14 \mathrm{~mm}$, respectively. The narrowest and shortest part of this region is the labyrinthine segment (23). The blood supply of the facial nerve is from different sources. The intratemporal part of the nerve is fed by both the carotid system and the vertebro-basilar system. The meatal segment is fed by the labyrinthine branch of the anterior inferior cerebellar artery, the geniculate ganglion is fed by the petrosal branch of the middle meningeal artery, and the tympanic and mastoid segments are fed by the stylomastoid branch of the posterior auricular artery (24). Among these vessels, there is a broad anastomotic network that surrounds the nerve. However, this anastomosis is weak in the labyrinthine segment. This structure suggests that ischemic attacks in this region may be excessive (25). Therefore, impaired perfusion in the blood flow of the labyrinthine segment may be an important cause for BP. Although it is argued that BP may be associated with dysfunction in small labyrinthine capillaries, the results of our study do not support this hypothesis.

The fallopian (facial) canal provides a protective pathway for the facial nerve in the temporal bone but also plays an important role in the pathophysiology of the injury (26). Narrow meatal foramen (5) and labyrinthine segment (27) are the regions where facial nerve edema leads to progressive compression, vascular reduction and axonal injury due to inflammatory or traumatic causes. This narrow segment is made even more vulnerable since it is a reservoir area between the terminal arterioles of the vertebrobasilar and external carotid artery systems. While the vertebrobasilar source feds through the labyrinthine branches of the anterior inferior cerebellar artery, the source of the external carotid artery is composed of the petrosal branch of the middle meningeal artery and the stylomastoid artery branching from the posterior auricular artery (28). The labyrinthine segment is made even more vulnerable by the lack of epineurium and associated vascular plexus which serves as a barrier to injury and provides a rich collateral blood supply. Anatomically, it is suggested that the blood supply to the labyrinthine segment is weak, so this part is very sensitive to ischemic attacks and that ischemic edema develops here (6). Impaired capillary density and reactivity may show microcirculatory damage since the capillary vessels at the labyrinthine segment are terminal-type vascular structure. Thus, the capillary density and reactivity may provide information about the development and prognosis of the disease.

In current studies, the $C D$ value is the number of spontaneously perfused capillaries and has been found to be $16 \%$ lower in early-onset coronary artery diseases

Table 1. The statistical analysis of the demographic information and the CD, PORH values of the patients in the BP and control groups

\begin{tabular}{|c|c|c|c|c|c|c|c|c|}
\hline & & \multicolumn{3}{|l|}{ BP group } & \multicolumn{3}{|c|}{ Control group } & \multirow{2}{*}{$\mathbf{p}$} \\
\hline & & \multicolumn{2}{|c|}{ Mean \pm SD, $(n \%)$} & Median & \multicolumn{2}{|c|}{ Mean \pm SD, $(n \%)$} & Median & \\
\hline \multicolumn{2}{|l|}{ Age } & \multicolumn{2}{|l|}{$31.7 \pm 8.4$} & 31.0 & \multicolumn{2}{|l|}{$32.5 \pm 8.0$} & 34.0 & $0.373^{m}$ \\
\hline \multirow{2}{*}{ Gender } & Female & 24 & $40.0 \%$ & - & 30 & $50.0 \%$ & - & \multirow{2}{*}{$0.274^{x}$} \\
\hline & Male & 36 & $60.0 \%$ & - & 30 & $50.0 \%$ & - & \\
\hline \multicolumn{2}{|c|}{ CD (Capiilary/mm²) } & $95.5 \pm 7.5$ & - & 96.0 & $96.4 \pm 7.2$ & & 98.3 & $0.437 \mathrm{~m}$ \\
\hline \multicolumn{2}{|c|}{ PORH (Capiilary/mm²) } & $95.8 \pm 7.5$ & - & 96.3 & $96.8 \pm 6.7$ & & 98.0 & $0.354 \mathrm{~m}$ \\
\hline
\end{tabular}

Table 2. The statistical analysis of the CD, PORH values in the complete recovery and incomplete recovery groups

\begin{tabular}{|l|l|l|l|l|l|}
\hline & Complete recovery & \multicolumn{2}{l|}{ Incomplete recovery } \\
\cline { 2 - 6 } & Mean \pm SD & Median & Mean \pm SD & Median & p \\
\hline CD (Capillary $/ \mathbf{m m}^{2}$ ) & $95.8 \pm 8.0$ & 95.5 & $94.6 \pm 5.6$ & 96.5 & $0.781 \mathrm{~m}$ \\
\hline PORH (Capillary $/ \mathbf{m m}^{2}$ ) & $96.7 \pm 7.8$ & 96.5 & $92.7 \pm 5.3$ & 96.0 & $0.118 \mathrm{~m}$ \\
\hline $\begin{array}{l}\text { CD: Capillary density, PORH: Post-occlusive reactive hyperemia, SD: Standard deviation } \\
\text { mMann-Whitney test }\end{array}$
\end{tabular}


compared with the normal population (29). However, in our study, the $C D$ value did not show a significant reduction in the $\mathrm{BP}$ patients compared with the normal population. $\mathrm{PORH}$, an indication of capillary recruitment, is associated with vascular endothelial function and has also been found to be $26 \%$ lower in early-onset coronary artery diseases. The $\mathrm{PORH}$ value is probably indicative of the release of endothelial vasoconstricting and vasodilating mediators and is a typical characteristic of this microvascular endothelial dysfunction (30). In our study, the $C D$ and PORH values were not significantly different between the groups that responded and did not respond to the treatment and did not provide any evidence for prognosis as an important marker.

\section{Study Limitations}

There were a few limitations in our study. The first of these was the subjective assessment of videocapillaryoscopy and the increased likelihood of biassed evaluation of the study because of a visible aesthetic facial defect in patients with BP. However, the likelihood of biassed evaluation of the study was reduced by the fact that the dermatologist made evaluations without knowing the diagnoses of the patients and did not know the HB grade of facial paralysis after 3 months. A second reason is that the study was conducted only in the Turkish race. It is known that cardiovascular risk factors change in different ethnic and national groups. Despite these limitations, we revealed that the $C D$ and $\mathrm{PORH}$ values were the same between the groups that responded and did not respond to the treatment in the BP patients compared with the normal population.

\section{Conclusion}

Even though the role of specific mechanisms in BP has not been fully understood, there was no significant difference between the BP patients and the healthy subjects and between the recovery and incomplete recovery groups with the capillaroscopic examination. It has been thought that the capillary density and reactivity values were normal in the BP patients and that a microvascular mechanism was not a possible factor for the development and prognosis.

\section{Authorship Contributions}

Concept: H.E.K., A.K.K. Design: H.E.K., A.K.K. Data Collection or Processing: A.K.K., H.A.U., H.A., M.Y. Analysis or Interpretation: H.A.U., B.Ç.E. Literature Search: K.H.K. Writing: H.E.K., A.K.K.

Conflict of Interest: No conflict of interest was declared by the authors.

Financial Disclosure: The authors declared that this study received no financial support.

\section{References}

1. Peitersen E. Bell's palsy: the spontaneous course of 2,500 peripheral facial nerve palsies of different etiologies. Acta Otolaryngol Suppl 2002;122:4-30.

2. Kefalidis G, Riga M, Argyropoulou P, et al. Is the width of the labyrinthine portion of the fallopian tube implicated in the pathophysiology of Bell's palsy: a prospective clinical study using computed tomography. Laryngoscope 2010;120:1203-7.

3. Murakami S, Mizobuchi M, Nakashiro Y, Doi T, Hato N, Yanagihara N. Bell palsy and herpes simplex virus: identification of viral DNA in endoneurial fluid and muscle. Ann Intern Med 1996;124:27-30.

4. Bibas $T$, Jiang $D$, Gleeson J. Disorders of the facial nerve. In: Gleeson M, ed. Scott-Brown's Otorhinolaryngology Head and Neck Surgery. 7th ed. London, England: Edward Arnold Ltd, 2008:3883-6.

5. Proctor B, Nager GT. The facial canal: Normal anatomy, variations and anomalies. Ann Otol Rhinol Laryngol 1982; $97: 33-61$.

6. Francis HW. Anatomy of the temporal bone, external ear, and middle ear. Cummings Otolaryngology-Head and Neck Surgery 6th Edition, Saunders, 2015, 1977-86.

7. Rizzoni D, Aalkjaer C, De Ciuceis C, et al. How to assess microvascular structure in humans. High Blood Press Cardiovasc 2011;18:169-77.

8. Roustit, M, Cracowski JL. Assessment of endothelial and neurovascular function in human skin microcirculation. Trends Pharmacol Sci 2013;34:373-84.

9. Holowatz LA, Thompson-Torgerson CS, Kenney WL. The human cutaneous circulation as a model of generalized microvascular function. J Appl Physiol 2018;105:370-2.

10. Shore AC. Capillaroscopy and the measurement of capillary pressure. Br J Clin Pharmacol 2000;50:501-13.

11. Tibirica E, Souza EG, De Lorenzo A, Oliveira GM. Reduced systemic microvascular density and reactivity in individuals with early onset coronary artery disease. Microvasc Res 2015;97:105-8.

12. House JW, Brackmann DE. Facial nerve grading system. Otolaryngol Head Neck Surg 1985;93:146-7.

13. Jeong JH, Sugii $Y$, Minamiyama M, Okamoto K. Measurement of RBC deformation and velocity in capillaries in vivo. Microvasc Res 2006;71:212-7.

14. Strauer BE. Significance of coronary circulation in hypertensive heart disease for development and prevention of heart failure. Am J Cardiol 1990;65:34-41.

15. Strain WD, Chaturvedi N, Hughes A, et al. Associations between cardiac target organ damage and microvascular dysfunction: the role of blood pressure. J Hypertens 2010;28:952-8.

16. De Boer MP, Meijer RI, Wijnstok NJ, et al. Microvascular Dysfunction: A Potential Mechanism in the Pathogenesis 
of Obesity-associated Insulin Resistance and Hypertension. Microcirculation 2012;19:5-18.

17. Levy BI, Schiffrin EL, Mourad JJ, et al. Impaired tissue perfusion: a pathology common to hypertension, obesity, and diabetes mellitus. Circulation 2008:118;968-76.

18. Anderson TJ, Charbonneau F, Title LM, et al. Microvascular function predicts cardiovascular events in primary prevention: long-term results from the Firefighters and Their Endothelium (FATE) study. Circulation 2011:123;163-9.

19. Adour KK, Byl FM, Hilsinger Jr RL, Kahn ZM, Sheldon MI. The true nature of Bell's palsy: analysis of 1000 consecutive patients. Laryngoscope 1978;88:787-801.

20. Adour KK, Bell DN, Hilsinger RL. Herpes simplex virus in idopathic facial paralysis (Bell's palsy). JAMA 1975;233:52730

21. Palva T, Hording L, Ylikoski J, Collan Y. Viral culture and electron microscopy of ganglion cells in Meniere's disease and Bell's palsy. Acta Otolaryngol (Stockh) 1978;86:269-75.

22. Fisch $U$, Felix $H$. On the pathogenesis of Bell's palsy. Acta Otolaryngol (Stockh) 1983;95:532-8.

23. Curtin HD, Gupta R, Bergeron RT. Embryology, anatomy and imaging of the temporal bone. Head and Neck Imaging. 5th ed. Philadelphia: Elsevier Mosby, 2011:1058-96.
24. Myckatyn TM, Mackinnon SE. A review of facial nerve anatomy. Semin Plast Surg 2004;18:5-12.

25. Mattox DE. Clinical Disorders of the Facial Nerve. Cummings Otolaryngology, 1998;170:2617-28.

26. Francis $H$. Facial nerve emergencies. In Eisele $D$, and McQuone $S$ (eds): Emergencies of the head and neck. St. Louis: Mosby, 2000. 337-66

27. Esslen E. The Acute Facial Palsies. Berlin: Springer-Verlag, 1977.

28. Jackson CG. Facial Nerve Paralysis: Diagnosis and treatment of lower motor neuron facial nerve lesions and facial paralysis: American Academy of Otolaryngology-Head and Neck Surgery Foundation, Inc., 1986.

29. Ijzerman RG, De Jongh RT, Beijk MAM, et al. Individuals at increased coronary heart disease risk are characterized by an impaired microvascular function in skin. Eur J Clin Invest 2003:33;536-42.

30. Serné, EH, Gans RO, ter Maaten JC, Tangelder GJ, Donker AJ, Stehouwer CD. Impaired skin capillary recruitment in essential hypertension is caused by both functional and structural capillary rarefaction. Hypertension 2001;38;238-42. 